\title{
Prevalence of gastrointestinal parasites in domestic dogs in Tabasco, southeastern Mexico
}

\author{
Prevalência de parasitas gastrointestinais em cães domésticos em Tabasco, sudeste do México \\ Oswaldo Margarito Torres-Chablé1*; Ricardo Alfonso García-Herrera ${ }^{1}$; Melchor Hernández-Hernández ${ }^{1}$; \\ Jorge Alonso Peralta-Torres ${ }^{1}$; Nadia Florencia Ojeda-Robertos ${ }^{1}$; Bradley John Blitvich ${ }^{2}$; Carlos Marcial Baak-Baak³; \\ Julián Everardo García-Rejón ${ }^{3}$; Carlos Ignacio Machain-Wiliams ${ }^{3}$ \\ ${ }^{1}$ División Académica de Ciencias Agropecuarias, Universidad Juárez Autónoma de Tabasco, Villahermosa, Tabasco, México \\ ${ }^{2}$ Department of Veterinary Microbiology and Preventive Medicine, College of Veterinary Medicine, Iowa State University, Ames, \\ Iowa, USA \\ ${ }^{3}$ Laboratorio de Arbovirología, Centro de Investigaciones Regionales Dr. Hideyo Noguchi, Universidad Autónoma de Yucatán, \\ Mérida, Yucatán, México
}

Received August 17, 2015

Accepted October 5, 2015

\begin{abstract}
The overall goal of this study was to estimate the prevalence of gastrointestinal (GI) parasites in dogs in the city of Villahermosa in Tabasco, Mexico. The study population consisted of 302 owned dogs that had limited access to public areas. A fecal sample was collected from each animal and examined for GI parasites by conventional macroscopic analysis and centrifugal flotation. Fecal samples from 80 (26.5\%) dogs contained GI parasites. Of these, 58 (19.2\%) were positive for helminths and $22(7.3 \%)$ were positive for protozoan parasites. At least seven parasitic species were identified. The most common parasite was Ancylostoma caninum which was detected in 48 (15.9\%) dogs. Other parasites detected on multiple occasions were Cystoisospora spp. $(\mathrm{n}=19)$, Toxocara canis $(\mathrm{n}=7)$ and Giardia spp. $(\mathrm{n}=3)$. Three additional parasites, Dipylidium caninum, Trichuris vulpis and Uncinaria spp., were each detected in a single dog. No mixed parasitic infections were identified. In summary, we report a moderately high prevalence of GI parasites in owned dogs in Villahermosa, Tabasco. Several parasitic species identified in this study are recognized zoonotic pathogens which illustrates the important need to routinely monitor and treat dogs that live in close proximity to humans for parasitic infections.
\end{abstract}

Keywords: Dogs, gastrointestinal, risk factors, zoonotic parasites, Mexico.

\section{Resumo}

O objetivo geral deste estudo foi estimar a prevalência de parasitas gastrointestinais (GI) em cães na cidade de Vilhahermosa, em Tabasco, México. A população estudada consistiu de 302 cães com donos, com acesso limitado a áreas públicas. Uma amostra fecal de cada animal foi coletada e examinada para parasitas GI por análise macroscópica convencional e centrífugo-flutuação. Amostras fecais de 80 (26,5\%) cães apresentaram parasitas GI. Destes, 58 (19,2\%) foram positivos para helmintos e $22(7,3 \%)$ foram positivos para protozoários. Pelo menos 7 espécies parasitas foram identificadas. O parasita mais comum foi Ancylostoma caninum, detectado em 48 (15,9\%) cães. Outros parasitas detectados em diversas ocasióes foram Cystoisospora spp. $(\mathrm{n}=19)$, Toxocara canis $(\mathrm{n}=7)$ e Giardia spp. $(\mathrm{n}=3)$. Adicionalmente, três parasitas foram detectados em apenas um cão - Dipylidium caninum, Trichuris vulpis e Uncinaria spp. Nenhuma infecção mista foi observada. Em resumo, nós identificamos neste trabalho uma prevalência moderadamente alta de parasitas GI em cães com donos, em Villahermosa, Tabasco. Várias espécies de parasitas identificados são reconhecidamente patógenos zoonóticos, o que indica a necessidade de monitorar rotineiramente e tratar infecçóes parasitárias em cães que vivem em proximidade a populaçóes humanas.

Palavras-chave: Cães, gastrointestinal, fatores de risco, parasitas zoonóticos, México. 


\section{Introduction}

Domestic dogs are important reservoirs of many zoonotic pathogens including several gastrointestinal (GI) parasites (ROBERTSON et al., 2000; ROBERTSON \& THOMPSON, 2002; TAN, 1997). One of the most common zoonotic GI parasites acquired from dogs is the roundworm Toxocara canis (LEE et al., 2010; MACPHERSON, 2013; OVERGAAUW \& VAN KNAPEN, 2013). In humans, T. canis infections can manifest as visceral larva migrans (a systemic disease caused by larval migration to major organs), ocular larva migrans (a disease limited to the eyes and optic nerves) and covert toxocariasis (a disease associated with eosinophilia, cognitive disturbances and asthma-like symptoms). Humans are usually infected by ingestion of embryonated eggs or larvae, and infections are more common among infants and children. Hookworms (i.e. Ancylostoma and Uncinaria spp.) are also zoonotic GI parasites commonly acquired from dogs (BOWMAN et al., 2010; ROBERTSON \& THOMPSON, 2002). Hookworm larvae can penetrate intact human skin and migrate through subcutaneous tissues, and this usually occurs after contact with soil contaminated with infected animal feces. In humans, hookworm infections can result in skin, enteric and pulmonary diseases such as cutaneous larva migrans. Hookworms commonly associated with cutaneous larva migrans include Ancylostoma braziliense, A. caninum and Uncinaria stenocephala. Dogs are also reservoirs of several protozoan parasites (i.e. Giardia duodenalis and Cystoisospora spp.) of zoonotic concern (FENG \& XIAO, 2011; ROBERTSON \& THOMPSON, 2002; RYAN \& CACCIO, 2013).

Monitoring dogs for zoonotic GI parasites is necessary for the development and implementation of effective control and prevention strategies that mitigate the burden of zoonotic diseases on public health. This is especially true in urbanized areas where humans and dogs are in frequent contact. Studies performed in the last few years have estimated the prevalence of GI parasites in dogs in many regions of the world including China (FANG et al., 2015), Demark (AL-SABI et al., 2013), Iran (GHAREKHANI, 2014), Italy (ZANZANI et al., 2014), Japan (KIMURA et al., 2013), Malaysia (NGUI et al., 2014), Portugal (MATEUS et al., 2014), Spain (ORTUNO et al., 2014) and Thailand (ROJEKITTIKHUN et al., 2014). However, there is no information on the prevalence of parasites in dogs in Tabasco, Mexico. To address this gap in our knowledge, we estimated the prevalence of GI parasites in owned dogs in Villahermosa, the largest city in the state of Tabasco.

\section{Materials and Methods}

\section{Study area}

The study was performed in the city of Villahermosa (population $\sim 650,000$ ) in Tabasco, southeastern Mexico. Villahermosa is located at Global Positioning Systems coordinates 17\% 99' N and $92^{\circ} 95^{\prime} \mathrm{W}$ and has an average elevation of approximately $10 \mathrm{~m}$. The climate is tropical with rain falling year around. The average annual temperature is $26^{\circ} \mathrm{C}$ (INEGI, 2015).

\section{Study population and sample collection}

The study population consisted of dogs that presented to the veterinary clinic at the Universidad Juarez Autonoma de Tabasco (UJAT) from January to December 2013. Dogs were classified according to their age ( $<12$ months or $>12$ months), gender, breed and anthelmintic usage (last treated $<12$ months ago, $>12$ months ago or never). Anthelmintic treatment usually consisted of a combination of pyrantel pamoate, praziquantel febantel and ivermectin which was administered perorally by a veterinarian. All dogs were primarily house-bound (had less than one hour of access to public areas each day). Individual fecal samples were collected directly from the rectum of each dog by rectal stimulation with parasitological loop or at the moment of defecation with the aid of the dog's owner. Samples were immediately transported to the laboratory on ice packs and refrigerated for no more than $24 \mathrm{hr}$ prior to processing.

\section{Parasitological procedures}

Fecal samples were first inspected for the presence of adult helminths and proglottids of cestodes using conventional macroscopic techniques. Samples were then assayed for eggs and oocysts using a centrifugation-flotation method as previously described (DRYDEN et al., 2005). Briefly, 2-5 g of each sample was mixed with $10 \mathrm{ml}$ of Sheather's sucrose solution (a saturated sugar solution with a specific gravity of 1.27 to 1.33 ). Samples were mixed thoroughly to disrupt aggregates and centrifuged ( 5 minutes at $1,000 \mathrm{~g}$ ). Eggs and oocysts were allowed to rise to the surface. A drop of each preparation was placed onto a slide and eggs and oocysts were visualized by light microscopy and identified according to morphological characteristics (BOWMAN \& GEORGI, 2009; MEDINA-REYNES, 1994). A fecal sample was considered to be positive if at least one parasitic form was observed by any method.

\section{Statistical analysis}

The association between parasite frequency and select demographic variables (age, gender, and deworming history) was assessed using $X^{2}$ test on $2 \times 2$ table and IBM SPSS Statistics version 22 software (IBM Corporation, Armonk, NY). Results were considered significant when $\mathrm{p}<0.05$.

\section{Results}

Fecal samples from 302 owned dogs that presented at the UJAT veterinary clinic from January to December 2013 were analyzed for the presence of parasites by macroscopic inspection and centrifugation-flotation. Samples from 80 (26.5\%) dogs tested positive by at least one of these methods (Table 1). The most common parasite was Ancylostoma caninum which was detected in the feces of 48 (15.9\%) dogs. Nineteen $(6.3 \%)$ dogs were positive for Cystoisospora spp., seven (2.3\%) dogs were positive for Toxocara canis and three (1.0\%) dogs were positive for 
Table 1. Prevalence of gastrointestinal parasites in fecal samples from 302 owned dogs in Villahermosa, Tabasco.

\begin{tabular}{|c|c|c|c|c|}
\hline \multirow[b]{2}{*}{ Parasite } & \multicolumn{4}{|c|}{ No. dogs positive for parasites } \\
\hline & $\begin{array}{l}\text { Positive by macroscopic } \\
\text { analysis only }\end{array}$ & $\begin{array}{l}\text { Positive by centrifugation- } \\
\text { flotation only }\end{array}$ & $\begin{array}{c}\text { Positive by } \\
\text { both detection techniques }\end{array}$ & $\begin{array}{c}\text { Total } \\
(\%)\end{array}$ \\
\hline Ancylostoma caninum & - & 48 & - & $\begin{array}{c}48 \\
(15.9)\end{array}$ \\
\hline Cystoisospora spp. & ${ }^{\mathrm{a} N} / \mathrm{A}$ & 19 & - & $\begin{array}{c}19 \\
(6.3)\end{array}$ \\
\hline Dipylidium caninum & 1 & - & - & $\begin{array}{c}1 \\
(0.3)\end{array}$ \\
\hline Giardia spp. & N/A & 3 & - & $\begin{array}{c}3 \\
(1.0)\end{array}$ \\
\hline Toxocara canis & 2 & 5 & - & $\begin{array}{c}7 \\
(2.3)\end{array}$ \\
\hline Trichuris vulpis & - & 1 & - & $\begin{array}{c}1 \\
(0.3)\end{array}$ \\
\hline Uncinaria spp. & - & 1 & - & $\begin{array}{c}1 \\
(0.3)\end{array}$ \\
\hline Total & 3 & 77 & - & $\begin{array}{c}80 \\
(26.5)\end{array}$ \\
\hline
\end{tabular}

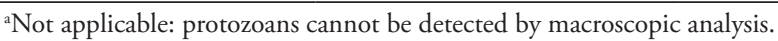

Table 2. Association between select demographic variables and parasite prevalence of 302 owned dogs in Villahermosa, Tabasco.

\begin{tabular}{llccc}
\hline & Variable & $\begin{array}{c}\text { No. dogs } \\
\text { tested }\end{array}$ & $\begin{array}{c}\text { No. dogs } \\
\text { positive }\end{array}$ & $\begin{array}{c}\text { \% dogs } \\
\text { positive }\end{array}$ \\
\hline Age: & $<12$ months & 172 & 31 & 18.0 \\
& $>12$ months & 130 & 49 & 37.7 \\
Gender: & Male & 141 & 41 & 29.1 \\
& Female & 161 & 39 & 24.2 \\
Breed: & Chihuahua & 27 & 7 & 25.9 \\
& Poodle & 31 & 4 & 12.9 \\
& Schnauzer & 44 & 8 & 18.2 \\
& Mixed-breed & 69 & 18 & 26.9 \\
& ather & 131 & 43 & 32.8 \\
\hline
\end{tabular}

a35 breeds.

Giardia spp. Other parasites detected were Dipylidium caninum, Trichuris vulpis and Uncinaria spp., which were each detected in a single dog. No dogs were concurrently infected with more than one parasite spp. Fifty-eight (19.2\%) dogs were positive for helminths and 22 (7.3\%) were positive for protozoan parasites.

The prevalence of parasites in dogs $<12$ months of age was $18.0 \%$ while the prevalence in $\operatorname{dogs}>12$ months of age $(37.7 \%)$ was approximately two-fold higher (Table 2$)$. Statistical analysis of these data revealed that this difference is significant $\left(X^{2}=15.05\right.$, d.f. $=1, P=0.0001)$. The prevalence of parasites in female and male dogs was $24.2 \%$ and $29.1 \%$, respectively. This difference is not significant $\left(X^{2}=0.91, d . f .=1, P=0.340\right)$. Our study population consisted of 233 pure-bred dogs and 69 mixed-breed dogs. Thirty-eight defined breeds were represented and the most common were schnauzers $(\mathrm{n}=44)$, poodles $(\mathrm{n}=31)$ and Chihuahuas $(\mathrm{n}=27)$. The prevalence of parasites in pure-bred and mixed-breed dogs was $26.6 \%$ and $26.9 \%$, respectively. This difference is not significant $\left(X^{2}=0.004, d . f .=1, P=0.947\right)$. The prevalence of parasites in schnauzers and non-schnauzers was $18.2 \%$ and $27.9 \%$, respectively, and this difference is also not significant $\left(X^{2}=1.123\right.$, d.f. $\left.=1, P=0.289\right)$. Likewise, the prevalence of parasites in poodles $(12.9 \%)$ compared all other dogs $(28.0 \%)$ as well as Chihuahuas (25.29\%) compared to all other dogs $(26.5 \%)$ did not differ significantly $\left(X^{2}=2.106\right.$, d.f. $=1, P=0.147$ and $X^{2}=0.003$, d.f. $=1, P=0.958$, respectively). A total of $204 \mathrm{dogs}$ had received anthelmintics within the last 12 months, 79 had last received anthelmintics more than 12 months ago and 19 had never received anthelmintics (Table 3). The overall GI parasite prevalence in dogs last dewormed $<12$ and $>12$ months ago (17.2\% and $22.8 \%$, respectively) are not significantly different from untreated dogs $(26.3 \%)\left(X^{2}=1.185, d . f .=1, P=0.276\right.$ and $X^{2}=0.991$, d.f. $=1, P=0.320$, respectively).

\section{Discussion}

This is the first study to estimate the prevalence of GI parasites in dogs in Tabasco. Similar studies have been performed in at least six other states of Mexico: Campeche (ENCALADA-MENA et al., 2011), Chiapas (MARTÍNEZ-BARBABOSA et al., 2008), Nuevo Leon (VARGAS-MENA \& DE BRONDO, 1967), Oaxaca (VELEZ-HERNANDEZ et al., 2014), Queretaro (CANTÓ et al., 2011) and Yucatan (RODRIGUEZ-VIVAS et al., 2011) in addition to Mexico City (EGUÍA-AGUILAR et al., 2005). The parasite prevalence reported in our study $(26.5 \%)$ is considerably lower than those observed elsewhere in Mexico. Parasites were detected in fecal samples obtained from 104 of 130 (80.0\%) domestic dogs in a rural community in Yucatan (RODRIGUEZ-VIVAS et al., 2011). Parasites were also detected in intestines harvested from 102 of $120(85.0 \%)$ stray dogs in Mexico City (EGUÍA-AGUILAR et al., 2005) and 275 of 378 (72.8\%) stray dogs in Queretaro (CANTÓ et al., 2011). Additionally, parasites were identified 
Table 3. Association between helminthic prevalence and anthelmintic treatment history for 302 owned dogs in Villahermosa, Tabasco.

\begin{tabular}{ccccccc}
\hline $\begin{array}{c}\text { Time since most } \\
\text { recent anthelmintic } \\
\text { treatment }\end{array}$ & A. caninum & D. caninum & T. canis & T. vulpis & Uncinaria spp. & Total No. dogs positive/ \\
tested (\%)
\end{tabular}

in 132 of $180(73.3 \%)$ canine fecal samples collected in various public locations in the city of Puerto Escondido, Oaxaca (VELEZHERNANDEZ et al., 2014) and in 74 of 200 (37.0\%) canine fecal samples collected in the streets of Cristobal de Las Casas, Chiapas (MARTÍNEZ-BARBABOSA et al., 2008).

A likely explanation for the lower prevalence of GI parasites reported in the present study compared to studies performed elsewhere in Mexico is because our sample population was comprised of dogs with limited access to public areas. Most other studies performed in Mexico focused on feral dogs or were performed using fecal samples collected in public areas. Free-roaming dogs are more likely to come into contact with infected dogs and infected fecal material compared to dogs primarily confined to residential properties. The differences in parasite prevalence could also be attributed to variations the detection techniques or the types of biological samples used in the above studies, or differences in the general health and nutritional status of the dogs. Alternatively, these differences could be due to temporal or spatial variations.

Another reason why the prevalence of GI parasites in this study is considerably lower than those performed elsewhere in Mexico could be because most dogs in our sample population had received anthelmintics in the last 12 months. As already noted, most other studies performed in Mexico focused on feral and/or free-roaming dogs, and these dogs are less likely to receive anthelmintics than those primarily restricted to private residences. However, it is important to note that we did not observe a significance difference in the prevalence of helminths in anthelmintic-treated dogs compared to untreated dogs. One limitation of our study is the small number $(n=19)$ of untreated dogs in the sample population which would have diminished the statistical power of the analysis. Alternatively, our findings could indicate that anthelmintics had limited (if any) effect on the prevalence of helminths in dogs in the sample population. Although many studies have demonstrated that anthelmintics significantly reduce the prevalence of helminths in dogs, this is not always the case. The administration of anthelmintics did not influence the prevalence of helminths in dogs in India (TRAUB et al., 2002). Additionally, helminths were detected on at least one occasion in 63 of 111 dogs (56.8\%) in Switzerland that were tested for parasites each month for 12 months, and given anthelmintics (pyrantel parmoate, praziquantel, febantel and ivermectin) every three months (SAGER et al., 2006). These findings could be attributed to anthelmintic resistance. Alternatively, anthelmintic treatment may not always result in a complete elimination of parasites. One limitation of our study is that parasites were not quantitated; thus, it is not known whether similar relative numbers of parasites were present in parasite-positive dogs that had received anthelmintics compared to parasite-positive dogs that had not received anthelmintics.

At least five helminth spp. (A. caninum, D. caninum, T. canis, T. vulpis and Uncinaria spp.) and two protozoan spp. (Cystoisospora spp. and Giardia spp.) were identified in the present study. The most common parasite was $A$. caninum which was detected in $15.9 \%$ of the sample population. Likewise, $A$. caninum was the most common parasite in the surveys performed in Yucatan and Mexico City where it was detected in $73.8 \%$ and $62.5 \%$ of dogs, respectively (EGUÍA-AGUILAR et al., 2005; RODRIGUEZVIVAS et al., 2011). A. caninum was the second most common parasite in dogs in Queretaro where it was detected in $42.9 \%$ of the sample population (CANTÓ et al., 2011). T. canis was detected in $2.3 \%$ of the dogs assessed in the present study. This parasite has been reported elsewhere in Mexico, including Yucatan (where $6.2 \%$ of dogs tested positive), Mexico City (13.3\%), Campeche (14.4\%), Queretaro (15.1\%) and Oaxaca (47.8\%) (CANTÓ et al., 2011; EGUÍA-AGUILAR et al., 2005; ENCALADA-MENA et al., 2011; RODRIGUEZ-VIVAS et al., 2011; VELEZ-HERNANDEZ et al., 2014).

No dogs in the present study were concurrently infected with more than one parasite species. In contrast, evidence of mixed parasite infections were detected in $49.5 \%$ dogs in Queretaro (CANTÓ et al., 2011) and 24.4\% dogs in Yucatan (RODRIGUEZ-VIVAS et al., 2011). These differences could reflect the lower overall GI parasite prevalence observed in our study $(26.5 \%)$ compared to the other two studies (72.8-80.0\%). Indeed, mixed infections are presumably less likely to occur when the overall parasite prevalence is approximately threefold lower. It is also possible that a subset of animals sampled in our study had mixed infections and that only the most abundant parasitic species was detected on each occasion.

Several of the GI parasites identified in the present study are of zoonotic concern. T. canis is a recognized cause of human disease; this pathogen has been associated with generalized lymphadenopathy, hepatitis, endomyocarditis, leukocytosis and irreversible blindness (MACPHERSON, 2013). Antibodies to Toxocara spp. were detected in $13.9 \%$ of individuals in the U.S. in 1988-1994, and increased seropositivity was associated with dog ownership (WON et al., 2008). It has been estimated that as many 
as 1.3-2.8 million individuals in the U.S. are infected with Toxocara spp. indicating that, even in developed countries, Toxocara spp. has an enormous burden on human health (HOTEZ, 2008). A. caninum has been associated with cutaneous larva migrans in humans (BOWMAN et al., 2010; ROBERTSON \& THOMPSON, 2002) and several cases of human disease have been attributed to D. caninum (BARTSOCAS et al., 1966; CURRIER et al., 1973; NEIRA et al., 2008), including a case that recently occurred in Sinaloa, Mexico (CABELLO et al., 2011). Several Cystoisospora and Giardia spp. parasites have been implicated in human disease (FENG \& XIAO, 2011; ROBERTSON \& THOMPSON, 2002; RYAN \& CACCIO, 2013).

In summary, we report a moderately high prevalence $(26.5 \%)$ of GI parasites in 302 owned dogs in the city of Villahermosa in Tabasco, Mexico. At least seven parasitic spp. were identified, several of which are recognized zoonotic pathogens. These data illustrate the important need to monitor and treat dogs that live in urban areas for GI parasites.

\section{References}

Al-Sabi MN, Kapel CM, Johansson A, Espersen MC, Koch J, Willesen JL. A coprological investigation of gastrointestinal and cardiopulmonary parasites in hunting dogs in Denmark. Vet Parasitol 2013; 196(3-4): 366372. http://dx.doi.org/10.1016/j.vetpar.2013.03.027. PMid:23602361.

Bartsocas CS, Von Graevenitz A, Blodgett F. Dipylidium infection in a 6-month-old infant. J Pediatr 1966; 69(5): 814-815. http://dx.doi. org/10.1016/S0022-3476(66)80132-4. PMid:5951581.

Bowman DD, Georgi JR. Georgis' parasitology for veterinarians. St. Louis: Saunders/Elsevier; 2009.

Bowman DD, Montgomery SP, Zajac AM, Eberhard ML, Kazacos KR. Hookworms of dogs and cats as agents of cutaneous larva migrans. Trends Parasitol 2010; 26(4): 162-167. http://dx.doi.org/10.1016/j. pt.2010.01.005. PMid:20189454.

Cabello RR, Ruiz AC, Feregrino RR, Romero LC, Feregrino RR, Zavala JT. Dipylidium caninum infection. BMJ Case Rep 2011; 2011. PMid:22674592.

Cantó GJ, Garcia MP, Garcia A, Guerrero MJ, Mosqueda J. The prevalence and abundance of helminth parasites in stray dogs from the city of Queretaro in central Mexico. J Helminthol 2011; 85(3): 263-269. http://dx.doi.org/10.1017/S0022149X10000544. PMid:20849669.

Currier RW 2nd, Kinzer GM, DeShields E. Dipylidium caninum infection in a 14-month-old child. South Med J 1973; 66(9): 1060-1062. http:// dx.doi.org/10.1097/00007611-197309000-00022. PMid:4739037.

Dryden MW, Payne PA, Ridley R, Smith V. Comparison of common fecal flotation techniques for the recovery of parasite eggs and oocysts. Vet Ther 2005; 6(1): 15-28. PMid:15906267.

Eguía-Aguilar P, Cruz-Reyes A, Martínez-Maya JJ. MartínezMartínezMaya JJ. Ecological analysis and description of the intestinal helminths present in dogs in Mexico City. Vet Parasitol 2005; 127(2): 139-146. http://dx.doi.org/10.1016/j.vetpar.2004.10.004. PMid:15631907.

Encalada-Mena LA, Duarte-Ubaldo EL, Vargaz-Magańa JJ, GarcíaRamírez MJ, Medina-Hernández RE. Prevalence of gastroenteric parasites of dogs in the city of Escárcega, Campeche, México. Universidad Ciencia 2011; 27(2): 209-217.
Fang F, Li J, Huang T, Guillot J, Huang W. Zoonotic helminths parasites in the digestive tract of feral dogs and cats in Guangxi, China. BMC Vet Res 2015; 11(1): 211. http://dx.doi.org/10.1186/s12917-015-0521-7. PMid:26276147.

Feng Y, Xiao L. Zoonotic potential and molecular epidemiology of Giardia species and giardiasis. Clin Microbiol Rev 2011; 24(1): 110-140. http:// dx.doi.org/10.1128/CMR.00033-10. PMid:21233509.

Gharekhani J. Study on gastrointestinal zoonotic parasites in pet dogs in Western Iran. Turkiye Parazitol Derg 2014; 38(3): 172-176. http:// dx.doi.org/10.5152/tpd.2014.3546. PMid:25308454.

Hotez PJ. Neglected infections of poverty in the United States of America. PLoS Negl Trop Dis 2008; 2(6): e256. http://dx.doi.org/10.1371/journal. pntd.0000256. PMid:18575621.

Instituto Nacional de Estadística y Geografía - INEGI. [online]. México; 2015 [cited 2015 April 22]. Available from: http://www.inegi.org.mx

Kimura A, Morishima Y, Nagahama S, Horikoshi T, Edagawa A, KawabuchiKurata T, et al. A coprological survey of intestinal helminthes in stray dogs captured in osaka prefecture, Japan. J Vet Med Sci 2013; 75(10): 1409-1411. http://dx.doi.org/10.1292/jvms.12-0499. PMid:23774027.

Lee AC, Schantz PM, Kazacos KR, Montgomery SP, Bowman DD. Epidemiologic and zoonotic aspects of ascarid infections in dogs and cats. Trends Parasitol 2010; 26(4): 155-161. http://dx.doi.org/10.1016/j. pt.2010.01.002. PMid:20172762.

Macpherson CN. The epidemiology and public health importance of toxocariasis: a zoonosis of global importance. Int J Parasitol 2013; 43(12-13): 999-1008. http://dx.doi.org/10.1016/j.ijpara.2013.07.004 PMid:23954435.

Martínez-Barbabosa I, Gutiérrez Cardenas EM, Alpizar Sosa EA, Pimienta Lastra RD. Parasitic contamination by dog feces collected from the streets of San Cristobal de Las Casas, Chiapas, Mexico. Veterinaria 2008; 39(2): 173-180.

Mateus TL, Castro A, Ribeiro JN, Vieira-Pinto M. Multiple zoonotic parasites identified in dog feces collected in Ponte de Lima, Portugal - a potential threat to human health. Int J Environ Res Public Health 2014; 11(9): 9050-9067. http://dx.doi.org/10.3390/ijerph110909050. PMid:25257358.

Medina Reynés U. Manual de técnicas de diagnóstico en parasitología veterinaria. Villahermosa: Centro de Investigación de Ciencias Agropecuarias, Unidad Sierra; 1994

Neira OP, Jofré ML, Muñoz SN. Dipylidium caninum infection in a 2 year old infant: case report and literature review. Rev Chilena Infectol 2008; 25(6): 465-471. PMid:19194613.

Ngui R, Lee SC, Yap NJ, Tan TK, Aidil RM, Chua KH, et al. Gastrointestinal parasites in rural dogs and cats in Selangor and Pahang states in Peninsular Malaysia. Acta Parasitol 2014; 59(4): 737-744. http://dx.doi.org/10.2478/ s11686-014-0306-3. PMid:25236287.

Ortuño A, Scorza V, Castella J, Lappin M. Prevalence of intestinal parasites in shelter and hunting dogs in Catalonia, Northeastern Spain. Vet J 2014; 199(3): 465-467. http://dx.doi.org/10.1016/j.tvjl.2013.11.022. PMid:24445136.

Overgaauw PA, Van Knapen F. Veterinary and public health aspects of Toxocara spp. Vet Parasitol 2013; 193(4): 398-403. http://dx.doi. org/10.1016/j.vetpar.2012.12.035. PMid:23305972.

Robertson ID, Irwin PJ, Lymbery AJ, Thompson RC. The role of companion animals in the emergence of parasitic zoonoses. Int J Parasitol 
2000; 30(12-13): 1369-1377. http://dx.doi.org/10.1016/S00207519(00)00134-X. PMid:11113262.

Robertson ID, Thompson RC. Enteric parasitic zoonoses of domesticated dogs and cats. Microbes Infect 2002; 4(8): 867-873. http://dx.doi. org/10.1016/S1286-4579(02)01607-6. PMid:12270734.

Rodríguez-Vivas RI, Gutierrez-Ruiz E, Bolio-González ME, Ruiz-Piña H, Ortega-Pacheco A, Reyes-Novelo E, et al. An epidemiological study of intestinal parasites of dogs from Yucatan, Mexico, and their risk to public health. Vector Borne Zoonotic Dis 2011; 11(8): 1141-1144. http:// dx.doi.org/10.1089/vbz.2010.0232. PMid:21395413.

Rojekittikhun W, Chaisiri K, Mahittikorn A, Pubampen S, Sa-Nguankiat $S$, Kusolsuk T, et al. Gastrointestinal parasites of dogs and cats in a refuge in Nakhon Nayok, Thailand. Southeast Asian J Trop Med Public Health 2014; 45(1): 31-39. PMid:24964651.

Ryan U, Caccio SM. Zoonotic potential of Giardia. Int J Parasitol 2013; 43(12-13): 943-956. http://dx.doi.org/10.1016/j.ijpara.2013.06.001. PMid:23856595.

Sager H, Moret CS, Grimm F, Deplazes P, Doherr MG, Gottstein B. Coprological study on intestinal helminths in Swiss dogs: temporal aspects of anthelminthic treatment. Parasitol Res 2006; 98(4): 333-338. http:// dx.doi.org/10.1007/s00436-005-0093-8. PMid:16374614.
Tan JS. Human zoonotic infections transmitted by dogs and cats. Arch Intern Med 1997; 157(17): 1933-1943. http://dx.doi.org/10.1001/ archinte.1997.00440380035003. PMid:9308505.

Traub RJ, Robertson ID, Irwin P, Mencke N, Thompson RC. The role of dogs in transmission of gastrointestinal parasites in a remote tea-growing community in northeastern India. Am J Trop Med Hyg 2002; 67(5): 539-545. PMid:12479559.

Vargas-Mena J, De Brondo MC. Intestinal helminthiasis in dogs in Monterrey City, N.L., Mexico. Bol Chil Parasitol 1967; 22(2): 53-55. PMid:5628892.

Vélez-Hernández L, Reyes-Barrera KL, Rojas-Almaráz D, CalderonOropeza MA, Cruz-Vázquez JK, Arcos-Garcia JL. Potential hazard of zoonotic parasites present in canine feces in Puerto Escondido, Oaxaca. Salud Publica Mex 2014; 56(6): 625-630. PMid:25604414.

Won KY, Kruszon-Moran D, Schantz PM, Jones JL. National seroprevalence and risk factors for Zoonotic Toxocara spp. infection. Am J Trop Med Hyg 2008; 79(4): 552-557. PMid:18840743.

Zanzani SA, Gazzonis AL, Scarpa P, Berrilli F, Manfredi MT. Intestinal parasites of owned dogs and cats from metropolitan and micropolitan areas: prevalence, zoonotic risks, and pet owner awareness in northern Italy. BioMed Res Int 2014; 696508: 696508. http://dx.doi.org/10.1155/2014/696508. PMid:24883320. 